\title{
CONTEMPORARY FUNDAMENTALISM AND FJM POTGIETER'S THEOLOGY
}

\author{
Hans SA Engdahl \\ University of the Western Cape
}

\begin{abstract}
In this article Afrikaner theology articulated by FJM Potgieter is compared to contemporary fundamentalism. Potgieter's theology is built on certain biblical principia that represent revealed truth and therefore are irreducible principles applicable in all spheres of life. These principles are also confirmed by common grace in the God-given dispensation of peoples and races. Contemporary fundamentalism would often begin with a select tradition that is strictly applied to the present. Often it is about a religious tradition that is used as a means to a political outcome. The article argues that Potgieter's theology has unmistakable elements of such contemporary fundamentalism.
\end{abstract}

Keywords: Contemporary Fundamentalism, Select tradition, Orthodoxy, Heterodoxy, Afrikaner theology, Apartheid, Pluriformity, Biblical Principles, Conservatism, Modernity

\section{Introduction}

This article attempts to demonstrate that FJM Potgieter's theology could be seen as an expression of contemporary fundamentalism. ${ }^{1}$ In order to achieve this I will give a short introduction of what should be called contemporary fundamentalism, making this kind distinct from biblical fundamentalism. Thereafter a similarly short introduction of Potgieter's theology will be given. In the comparison it should be clear that they are not equals. Potgieter's theology has more to it than what could relate to this particular ideology. And still there are strong affinities. Contemporary fundamentalism has a structure that is definable. The nature of fundamentalism is crude, obvious, down to earth. In my previous research, I have argued that contemporary fundamentalism could serve as a grid to Potgieter's theology. Here it would be enough to put the one over against the other in order to demonstrate a certain affinity. ${ }^{2}$

One should, however, note that we then would compare phenomena that did not appear at the same time. This present form that we call 'contemporary fundamentalism' for want of anything better did not exist at the time of Potgieter. But being in a way a child of Biblical fundamentalism he in fact had more in common with this latter day phenomenon. This is typically post-modern and post-Potgieter. Yet my contention is that one can very well be

\footnotetext{
One section of my dissertation deals with contemporary fundamentalism as a point of departure for understanding Potgieter's theology, see Hans SA Engdahl, Theology in Conflict. Readings in Afrikaner Theology. The Theologies of FJM Potgieter and BJ Marais. Frankfurt am Main: Peter Lang, 2006. Frederik Johannes Mentz Potgieter (1907-1992), was professor at Stellenbosch, in Church History and the History of Dogma 1946-1960, and in Dogmatics 1960-1977, Engdahl, p. 61.

2 I then argued for a 'contrast reading' in the following way. I used that concept in my dissertation as my second reading of both FJM Potgieter and BJ Marais, two influential theologians from the same Afrikaner background. In this kind of contrast reading the word contrast is used in its nearness, as something "that holds a certain comparability or analogy, a contrast as a (slightly) different shade". There are other kinds of readings where contrast would be more drastic and lean towards understandings like 'contrariety', Engdahl, p. 21.
} 
permitted to take out phenomena and texts from various contexts and compare them. We may gain some knowledge today that was simply not available 20 years ago. Perhaps one should add that other readings are also possible.

\section{Fundamentalism}

\section{Introduction}

The use of fundamentalism as a scientific term denoting a phenomenon in the main World Religions today has been questioned in various ways but also found to be most appropriate. ${ }^{3}$ In a striking way the last two decades allow us to see similar developments not only within Christianity, Islam and Judaism but also in Sikhism, Hinduism, Buddhism and Confucianism.

The first impression might be a movement that is ultra-conservative. What it rather amounts to is a movement that makes use of religious fundamentals in order to impact on modern society. The sectarian redefinition of society is not to be seen as a withdrawal but rather as a return from the margin to a more central position. More often than not this return to modern society is closely linked with a political agenda and a surge for power. ${ }^{4}$ Moreover, fundamentalism is a fairly easily definable phenomenon. It could be seen as a tendency of some members of traditional religious communities to separate from fellow believers and to redefine the sacred community in terms of its disciplined oppositions to non-believers and 'lukewarm' believers alike. 'Fundamentalists' within these historic religious traditions, convinced of the conspiratorial nature of secularists and liberal religionists, adopted a set of strategies for fighting back against what is perceived as a concerted effort by secular states or elements within them to push people of religious consciousness and conscience to the margins of society. The religious ideologues established new boundaries between 'insiders' and 'outsiders' and imposed a strict discipline on their followers; in many if not all cases, they were able to elevate their mission to a spiritual plane in which eschatological expectation and apocalyptic urgency informed even the most mundane world-building tasks of the group. ${ }^{5}$

3 It is undoubtedly a Protestant, Western term from the beginning and has often been used in a derogative way. Protestants in the US in the late $19^{\text {th }}$ and early $20^{\text {th }}$ century coined this phrase regarding themselves in defending as they saw it the 'fundamentals' of the Christian faith, see Nancy T Ammerman, etc. in Martin E Marty and R Scott Appleby, editors, Fundamentalisms Observed. Chicago, 1991:1-65; see also George M Marsden, Fundamentalism and American Culture. New York: Oxford University Press, 1980. Despite the term being Western and used pejoratively, quite a lot speaks in favour. "Among the reasons for insistence on a single term are these: First, 'fundamentalism' is here to stay, since it serves to create a distinction over against cognate but not fully appropriate words such as 'traditionalism', 'conservatism', or 'orthodoxy' and 'orthopraxis'. If the term were to be rejected, the public would have to find some other word if it is to make sense of a set of global phenomena, which urgently bid to be understood. However diverse the expressions are, they present themselves as movements which demand comparison even as they deserve fair separate treatment so that their special integrities will appear in bold relief. Second, when they must communicate across cultures, journalists, public officials, scholars, and publics in the part of the world where these books have their audience have settled on this term... Having spent two of the five years set aside for research and study comparing 'fundamentalism' to alternatives, we have come to two conclusions. No other coordinating term was found to be as intelligible and serviceable. And attempts of particular essayists to provide distinctive but in the end confusing alternatives led to the conclusion that they were describing something similar to what are here called fundamentalisms", Marty and Scott Appleby, "The Fundamentalism Project: A User's Guide" in Fundamentalisms Observed, pp. vii-xiii, p. viii.

4 The findings in the Fundamentalism Project confirm this.

5 See Introduction, Fundamentalisms Comprehended. Chicago and London, 1995:1. This is part of the Fundamentalism Project that took shape in the mid-1990s, see Martin E. Marty and R. Scott Appleby (editors), The Fundamentalism Project, volume 1-5. Chicago: University of Chicago Press, 1992-95. Volume 
Various, religious traditions could be seen to have a lot in common:

[R]adical Shi'ite Muslims in Lebanon and Iran, militant Sikhs in Punjab, Jewish extremists on the West Bank, Hindu nationalists at Ayodhya, and Christian cultural warriors in the United States... were establishing 'progressive', world-creating and worldconquering movements that looked to the past for inspiration rather than for a blueprint...Thus fundamentalists are important players in local, regional and even national politics not as a result of their nostalgia or 'backwardness', by which their under estimators often know them, but for their ability to adapt to modern organizational imperatives, political strategies, communications advances, and economic theories. ${ }^{6}$

It is hardly meaningful to summarize fundamentalism only in a few points. ${ }^{7}$ As a contemporary phenomenon, and therefore elusive in certain ways, it asks for some kind of description. This we will do, if only in a brief and condensed way, and at the end still come up with a summary. A short outline of recent research on fundamentalism will hopefully be useful.

\section{The Anatomy of Fundamentalism}

It could be argued that all the presently known examples of fundamentalism are part of the great religious traditions that evolved for well over one thousand years from $500 \mathrm{~B} \mathrm{C}$. The Axial Age civilisations have a built-in tension between the transcendental and the mundane and fundamentalism is a part of this history. ${ }^{8}$ One could also say that there is a direct relationship between "utopian visions in Axial Civilizations" and later modern forms of fundamentalism. ${ }^{9}$ The latter, however, would not make do with a utopia that is of a higher or transcendent order. Characteristic for a modern type fundamentalism is that it "aims at the reconstruction of the existing order, according to what is promulgated as the pristine 'original' vision of the given religion; a vision most fully realized in the past - and they are oriented against the existing situation into which religion has degenerated." 10

An impression often created is that fundamentalism is an anti-phenomenon in the world of modernity. As will be demonstrated fundamentalism is certainly basing its conviction on an original, religious fundament, but at the same time deeply embedded in modernity. Some would even argue that it is fully a part of modernity.

1: Fundamentalisms Observed (1991); volume 2: Fundamentalisms and Society (1993); volume 3:

Fundamentalisms and the State (1993); volume 4: Accounting for Fundamentalisms (1994); volume 5: Fundamentalisms Comprehended (1995).

6 Ibid, p. 2.

7 We will here largely follow the Fundamentalism Project, which moves within the social sciences: "Not by design or intent but by sheer force of momentum and material available, social scientists have dominated this five-volume survey of fundamentalisms. Regrettably, the humanities have been less in evidence in a project that purports to be interdisciplinary", ibid. p. 6. Somehow we will have to make up for an apparent marginalisation of theology (my comment).

8 "By Axial Age civilizations (to use Karl Jaspers's nomenclature), I refer to those civilizations that crystallized during the thousand years from $500 \mathrm{BCE}$ to the first century $\mathrm{CE}$, within which new types of ontological visions, of conceptions of a basic tension between the transcendental and mundane orders, emerged and were institutionalized in many parts in the world; in ancient Israel, later in Second Commonwealth Judaism and Christianity, ancient Greece, Zoroastrian Iran, early imperial China, Hinduism and Buddhism, and, beyond the Axial Age proper, Islam”, S. N. Eisenstadt, 'Fundamentalism, Phenomenology, and Comparative

Dimensions', in Fundamentalisms Comprehended, p. 260.

9 Eisenstadt, p. 262.

$10 \quad$ Ibid, pp. 262f. 
Modern fundamentalist movements could be said to have built-in conflict in that they could be said to represent both old and new at the same time. The close relation to modernity is evident in several ways, not least in terms of organisational characteristics and ideology. Such organisational characteristics are "the very tight party-like discipline, and in the use of modern communication technologies and modern propaganda techniques". 11

When it comes to ideology one is faced with a paradoxical situation; "[ $t]$ he basic ideology of fundamentalism is anti-modern: the negation of some of the basic tenets of modernity - of the autonomy of the individual, of the hegemony of reason, of the ideology of progress, and the like - and of modernity as a civilization, although not necessarily of its technological or organizational aspects.",

Another three aspects should be added to a description of the anatomy of fundamentalism.

First, fundamentalist ideologies appear as very modern and above all revolutionary in their tendencies. They are in effect "overarching totalitarian all-encompassing ideologies, which emphasize a total reconstitution of the social and political order, and which espouse a strong universalistic, missionary zeal. These characteristics of the modern fundamentalist movements are reminiscent of the great revolutions."13 What they share with these revolutions is the heterodox interpretation of the monotheistic axial civilisations into a present day reality and programme.

Put differently: the primacy of politics is striking, something which modern fundamentalism shares with the great modern revolutions, "albeit of religious politics or of politics guided by a totalistic religious vision to construct society, or sectors thereof". ${ }^{14}$ There is also a continuous tension between a strongly participatory society and authoritarian leadership principles. Most sectarian movements have the same tension inherent in them, but is here made worse. ${ }^{15}$

Secondly, fundamentalism is heterodox while all the time claiming to be exponents of the orthodox tradition. It makes sense to talk about this deviation only where there is an orthodox tradition. This presupposes a strong adherence to a holy book and to a developed doctrinal system. The Christian Bible and the Qur'an come into focus, and in the Christian tradition Protestantism, especially sectarian Protestantism have given rise to fundamentalism. This is also where there are claims to orthodoxy while what is unfolding is de facto heterodoxy. ${ }^{16}$

Axial religions with a strong transcendent and mundane emphasis at the same time here come into focus. Yet, there are noticeable differences. "[T]he Jewish Bible - the 'Old Testament' - did not enjoy in the Jewish tradition such authority as the Qur'an or the Bible in Protestantism. It was, at least in rabbinical Judaism, open to many interpretations."17

However, a pristine vision did not have to be based on a holy book. "The most important such selection is the very emphasis on some original pristine vision or symbol of a tradition - especially on some book or some pristine canon, or for instance on the sanctity

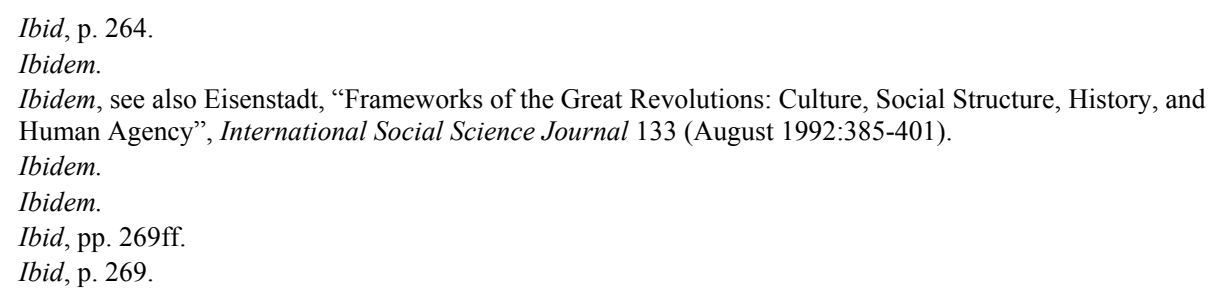


of the land of Israel in the ideology of the Gush Emunim - as the main, even the single, focus of the tradition." ${ }^{\prime 8}$ No doubt the tendency towards fundamentalism is stronger in civilisations, "in which there is a strong emphasis on the reconstruction of the mundane world on the basis of a transcendental otherworldly vision.,"19

Thirdly, fundamentalism is a reconstruction of select traditions. A parallel to the discussion on deviations from orthodoxy is the role of tradition within fundamentalism. One could here talk about a reconstruction or ideologisation of tradition. In order to get inside the dynamics of this movement one has to see how far it is from the carrying on of tradition in the "traditional' sense. There is no tolerance "against any innovation or lenience within the existing traditions - even if such innovation has been a continuous component in such a tradition." One is here reminded of an Eastern European fundamentalist exponent of Jewish Orthodoxy during the first part of the nineteenth century, Hatam Sofer, whose injunction was "anything new is forbidden from Torah", and how far this statement really was from traditional Jewish interpretation of the Torah. ${ }^{20}$

What happens is apparently a monopolisation of a certain element of the tradition in question and a banning of all diversity and plurality.

It is not ... just the selection of a certain theme or symbol of tradition as against others that is characteristic of the various fundamentalist movements. It is rather the attempt at the totalization of this vision that is crucial here - the subordination of different aspects and layers of tradition under the presumed implications of this single principle and their concomitant hierarchization. $^{21}$

The 'reaction' to modernity is in several ways paradoxical.

Although seemingly traditional, in fact these movements are in some paradoxical way anti-traditional. They are anti-traditional in the sense that they negate the living tradition, with its complexity and heterogeneity, and instead they uphold a highly ideological conception of tradition as an overarching principle of cognitive and social organization. ${ }^{22}$

What we are dealing with is thus a movement that is modern in its anti-modernity in that it makes use of some fundamental of tradition in a selective way and by doing so also becomes anti-tradition in its selectivity.

Exponents find themselves in a situation where they are called to defend the fundamental faith that the religious establishment already is perceived to have abandoned:

The most central focus of the attack of fundamentalist movements is that many sectors of the society, and above all the religious establishment, deviate from the traditional life and give in to the temptation of power and wealth. Fundamentalist movements develop among those groups that perceive their civilizations - the basic religious premises of their civilization - as threatened by others, especially by the component of reason; in modern times by modern (Western) civilization. ${ }^{23}$

Ibid, p. 266

Ibid, p. 271

20 Such a word "went against the great and continuous tradition of interpretation and innovation that characterized the classical (medieval and early modern) Jewish tradition". See also Michael K. Silber, "The Emergence of Ultra-Orthodoxy: The Invention of a Tradition", in J. Wertheimer, editor, The Uses of Tradition. Cambridge, Harvard University Press, 1992, ibid p. 266.

${ }^{21}$ Ibid, p. 266.

22 Ibidem.

23 Ibid, p. 273 


\section{Fundamentalist Summary}

A clear picture emerges; it is possible to describe a substantial part of fundamentalist anatomy. Yet, there is a major uncertainty or tension that is unresolved. On the one hand fundamentalism has claims that are universalistic and it is clearly demonstrated that there are links to other heterodox movements emanating from axial orthodox religions such as revolutionary movements. There is a claim to radically change this world here and now.

On the other hand, fundamentalism is described as enclave and even as sectarian. Frequently there is an ethnic or nationalist confinement. We do not need to resolve this tension or eradicate this uncertainty. Both descriptions may be adequate and just. Both may point at another tension that also makes fundamentalism volatile, unpredictable. We have already detected a contradiction of a similar magnitude, namely that of using primeval religious fundamentals for a contemporary political agenda.

We will now draw some conclusions of what has already been said, so as to form a basis for our own reading. ${ }^{24}$ First of all it is clear that fundamentalism is discontented with and bears a grudge over against the own grouping. Without exception it seems to be the case that the problems start at home, as it were. A typical example is a society, traditionally very religious, that has become secularised and more or less indifferent to a religious outlook. It is understood that there is a dire need for a moral and religious renewal.

Secondly it is striking that the overarching principle in fundamentalism is religious belief. It is a religious belief that in most cases stems from the traditional, transcendent religions with a sovereign, supreme God, i e Judaism, Christianity and Islam. There seems to be an absolute conviction that only through divine intervention things will come right. Furthermore it is typical of fundamentalism to select a few religious fundamentals and build a system on these. One result of this selectivity is that other elements in the tradition in question will become subordinate and perhaps redundant.

Thirdly one can see that the religious fundamentals selected are there for a wider and more ultimate purpose. They serve more than anything else as the basis of a political agenda. In turn, the political agenda creates an unavoidable surge for power, from the periphery to the centre, from enclave to hegemony. The setting up of a political agenda means an absolute preparedness for execution of power, which may include aggressive power, violence and war. There are normally no inhibitions regarding the use of aggressive power. The religious fundamentals are such that they by principle condone violence if it serves a 'rightful' purpose.

Fourthly there is a time constraint. There is an interesting and sometimes conflictive interaction between the religious fundamentals and the political agenda. They can also mutually support and confirm each other. One result of this interaction is that the political agenda has to be worked out under time constraint. The religious perspective is namely almost always eschatological in the sense of imminent crisis. The perception is that you are at the end of times. The perspective is eschatological and the solution is realized eschatology.

Fifthly, in drawing up a moral code and a political agenda it becomes a primary concern to establish external boundaries. What is needed is a "wall of virtue". There is also a constant need for an enemy. It could be the own lukewarm and secularised society and culture, but it could also be the dominant power in the region or in the world. One could

24 The Fundamentalism Project has an extensive summary of more than one hundred pages, Fundamentalisms Comprehended, volume 5:399-504. 
talk about an ascent from an enemy identified in the home sphere to an enemy on the wider regional or world level. It could also be an oscillation between the home enemy and the world enemy.

Finally, the fixed political agenda and not necessarily the religious fundamentals only, lead to a sectarian worldview quite unfit to rule or save mankind. ${ }^{25}$ Even so this sectarian worldview may well aspire to greater things, like a universalistic and revolutionary outcome. $^{26}$

Fundamentalism is inherently anti-traditional in that it selects certain fundamentals and rejects the others in that particular tradition. Consequently fundamentalism is inherently heterodox, while all the time claiming to be orthodox. Interpretation is superfluous. "The fundamentalist groups espouse a principled denial of interpretation, which does, of course, in itself constitute a distinct, new and innovative mode of interpretation." 27

Fundamentalism is also anti-modern but at the same time completely conditioned by modernity in that it thrives on modernity. "We are facing a by and large modern movement." 28

A situation of great diversification and fragmentation is a fertile ground for fundamentalism.

At the same time there is an affinity to the great modern revolutions through a primordial collective memory and tendencies to Jacobinism. One should also bear in mind that within one and the same religion there might develop several contradictory, rival fundamentalist movements.

\section{Potgieter's Theology}

A close reading of the whole body of theological texts in the authorship of Potgieter would naturally yield fruits of the most varied kind. ${ }^{29}$ The reason for this is his method, which in short form is as follows. Holy Scripture contains fundamental principles, which are axiomatic and basic forms of revelation. These principles provide a ground for theology, as well as for philosophy. Differently put, these principles form a basis for the Christian faith but also for all science. There is therefore no area of knowledge or existence that cannot be addressed from the point of view of Scripture.

Potgieter lives up to this claim in the sense that he unreservedly tackles problems and questions of most wide varieties. The close reading gives some evidence of this. We will here in this summary concentrate on four major issues in his theology namely neoCalvinism, God and science, verbal inspiration and apartheid.

Potgieter could certainly be called a neo-Calvinist. He remained a close associate of the Vrije Universiteit in Amsterdam, having this university at heart his whole life. That is, he had, already as a doctoral student there in the $1930 \mathrm{~s}$, adopted the neo-Calvinist life view. ${ }^{30}$ The prime authority (next to Calvin) was without competition Abraham Kuyper. As Potgieter writes his dissertation on Jean Calvin there is every reason to scrutinize his

\footnotetext{
See Emmanuel Sivan, 'The Enclave Culture', in Fundamentalisms Comprehended.

See SN Eisenstadt, 'Fundamentalism, Phenomenology, and Comparative Dimensions', in ibidem, p. 264.

Ibid, p. 266.

Fundamentalism within Hinduism today is a case in point, ibid p. 272.

Engdahl, chapter 3, pp. 61-142; for Potgieter's writings see the bibliography in my dissertation.

30 FJM Potgieter, Die Verhouding tussen die Teologie en die Filosofie by Calvyn. Amsterdam, 1939, being his dissertation.
} 
scholarship in this regard. It is then not so surprising, but at the same time gravely disappointing, that he at no time, as far as I have been able to see, deviates from Kuyper or neo-Calvinism when interpreting Calvin. Kuyper was very influential from the inauguration of the new university in 1880 until the 1920s in the Netherlands, in theology and politics. He was a giant. His notions of sphere sovereignty and Calvinism as a life system have influenced the Dutch society and church life well beyond World War Two. ${ }^{31}$ At the same time, however, there were other schools of thought in sharp conflict with Kuyper in the country, but of course hardly at Vrije Universiteit - at least not in its early history. Could the same be said about Stellenbosch? During the years that Potgieter was professor there, first in Church History and Dogma, then in Dogmatics, from 1946-1977, what was the discourse on Calvin like? My impression from his own writings is that he hardly was challenged or questioned in a substantial way by his own colleagues during this long period, not so long ago. One reason for making this possible was most likely the legacy of the so-called Du Plessis affair already in the 1930s, as a result of which historic criticism of the Bible was silenced. ${ }^{32}$

Not without significance is the fact that Potgieter, with the help of his neo-Calvinism, lays the foundation early on of his theology in such a way that he without friction whenever suitable can plug into the 'new' dispensation of apartheid. The best example of this is found in his exposé of Calvin and Scripture. He has a profound discussion as to how one should understand Calvin's theology. What is the key to his theology? Scholars had tried hard to come up with one particular key, but they all fall short. A theistic emphasis is important to Potgieter, but many draw wrongly from this the inference that Calvin's theology is defined either through the sovereignty of God, the glory of God, Predestination or Providence. They are all there, but none of them would qualify as the key to his theology. The answer lies elsewhere and I am not at all a stranger to the idea that Potgieter here is right regarding Calvin. He says that the key to Calvin is to understand that Scripture is absolutely central to his theology, but never through a particular dogma or concept. Rather, it is the plurality of truths in Scripture that is important. It is a convincing argument as Calvin was keen to say that the revelatory truths are so great that no human could possibly receive it through one single word or formulation. A plurality of truths and principles is the answer. ${ }^{33}$

Already here one should pay attention to the fact that Potgieter uses this insight in his wider theological framework most consistently. In fact, and I think I have demonstrated this in my dissertation, he uses this truth as conducive to structures laid down in creation through common grace, that is the pluriformity in life. In doing so he is able to argue that this pluriformity, applicable to everything from national and ethnic identities to church realities, is grounded in revelatory principles, axiomatic and irreversibly laid down in Scripture. $^{34}$

Potgieter's theology is consistently deductive and that can easily be understood from the above discussion on Scriptural principles. This consistency is a sign of strength and on a par with that a further strength shows itself, namely his emphasis on openly declared points

31 Abraham Kuyper, 1837-1920, Dutch theologian, church leader, politician, journalist and educationalist. See for example James D Bratt (ed.), Abraham Kuyper, A Centennial Reader. Grand Rapids, Michigan: Eerdmans, 1998.

32 Engdahl, p. 47, see also Johann Kinghorn in Johann Kinghorn (ed.), Die NG Kerk en Apartheid. Johannesburg: Macmillan Suid-Afrika, 1986:62; 55 f.

33 Engdahl, p. 75-90, Potgieter, Die Verhouding tussen die Teologie en die Filosofie by Calvyn, p. 76.

34 See for example Engdahl, p. 121 and Potgieter, Kerk en samelewing - 'n wesenskou. Cape Town: NG Kerkuitgewers, 1990:45. 
of departure in any scientific discourse. His critique of positivism is clear and logic: the claim that "science does not have any presuppositions, is itself a presupposition that is not sustainable but self-contradictory". ${ }^{35}$ What is also of interest and worthy of a discussion of its own is his insistence that to a theologian the real, important presuppositions are those of faith. "The very belief in the existence of God is decisive also to science." 36

The consistency, with which he sticks to a deductive way of working with openly declared presuppositions, also creates unforeseen problems. A lack of sensitivity regarding the empirical, not totally unexpected from a biblically based theologian, becomes an extra burden. It is probably quite unusual that still in the 1950s it was possible to maintain what Potgieter did, at least in a serious academic institution. On one occasion during this decade he spoke to medical students of Stellenbosch, as well as the University of Cape Town. Here he actually warns those who do not take the Word of God seriously regarding what God laid down in creation. One of his presupposed statements of faith then in fact is that God created the human being in one original act of creation. No evolutionism to talk about here, no development from an animal stage to that of humans. It is evident that he stays away from any talk of "the fundamental unity of life in its origins". There was a "divinely ordained diversity and plurality" in the original act of creation. ${ }^{37}$

Potgieter holds a view that the Bible is the inspired Word of God. It is more precisely a doctrine of verbal inspiration that he advocates, but an organic verbal inspiration rather than a mechanistic inspiration. The belief that the words were dictated to and through the writers also finds some support in Calvin. What further has to be upheld is the inerrancy of the Bible. The inspired word has to be taken literally, so that each word in effect is inspired by God through the Holy Spirit. ${ }^{38}$

His way of defending his position is noteworthy. He argues in contradistinction to the most influential theologian of the century, Karl Barth. According to Potgieter the latter falls short on the following points. First, his theology is marked by existentialism in the sense of mobility and change. There is no room for the very being and essence of God, and therefore one can assume that little room is given to belief in the Word as a constantly inspired word, a word with the indwelling spirit.

Secondly Barth makes the obvious mistake insisting that the Word of God also is a human word. Potgieter's problem is that having said that everything is inspired by God, little room is left for criticism or questions regarding how these words in fact came into being, humanly speaking. The interesting thing is that Barth is able to talk about the word as a fallible word taken down by very fallible human beings and at the same time maintaining that it is in a decisive way the Word of God. Barth also accuses exponents of the inerrancy doctrine that they have given rise to a Verweltlichung of the whole concept of revelation. It has historically (especially during the $17^{\text {th }}$ century) given rise to atheism as faith in God was intimately linked to a view of Scripture as inerrant and infallible; this claim was all too easy to refute with a secularisation and disbelief as a result. In my dissertation I have in deliberations with Potgieter and Barth extended the sources used by

Engdahl, p. 90, Potgieter, Die Verhouding tussen die Teologie en die Filosofie by Calvyn, p. 93.

36 Engdahl, p. 91, Potgieter, 'Die Universiteit op Teosentriese Grondslag' in Polumnia. Jaargang 15-1959 (Eeufeesuitgawe) pp. 214-218, p. 214f, (also in Die Gereformeerde Vaandel, Junie 1955).

37 Engdahl, p. 99, Potgieter, 'Weerspreek die gedagtes van skepping en evolusie mekaar?' in Die Gereformeerde Vaandel. Pretoria, September 1952:155-167; 167.

38 For the discussion on verbal inspiration and Karl Barth see Engdahl, pp. 104-115, see also Potgieter, 'Die Skrifbeskouing van Barth' in Die Gereformeerde Vaandel, September 1954:31-38, and Potgieter, Die Teopneustie van die Heilige Skrif met besondere verwysing na Karl Barth. Cape Town and Pretoria, 1963. 
Potgieter and actively engaged on the side of Barth. The theological content was all too important just to be left to question marks in Potgieter's margin.

The fact that Barth can argue for an open Biblical canon is anathema to Potgieter, but to me a sign that it is possible to have an open view of Scripture as human scripture and at the same be able to claim that these texts are inspired Words of God. In light of this it becomes difficult to follow Potgieter's analogy between the Scriptural word and the Word incarnate. He argues that the Word of God has become the Scriptural Word of God in the same way as the Word of God has been made flesh (Christ). As Christ was without sin, even though limited in human form, the Scriptural Word also is inerrant in all ways. One can here warn that it sounds like a parallel incarnation rending the incarnation of Christ superfluous.

Much could be said about how Potgieter effectively argues for a church that is conformed to the rest of the world falling under common grace. The pluriformity in the world and in society at large is valid also in the church. Hence is unity in any visible form of the church not to be expected in this aeon.

Let us also dwell for a moment on the clear deductions in his thinking leading to an unreserved legitimisation of the societal and political system of apartheid. Potgieter is low key to say the least. He neither talks much about the Afrikaner nation, nor much about nationalism. A national or ethnic identity in the form of Afrikanerdom is taken for granted; hence not much need for talk about it. There is also not much talk about apartheid except in a few articles that expressly deal with the subject. What is more deceiving is that his deductions in favour of justifying apartheid to a large extent are dressed in more tolerable Kuyperian clothes. Nevertheless once in a while things are shown forth as they really are. One such occasion, and I wonder whether anyone still is around to have experienced the moment - the hall in the Kweekskool at Stellenbosch apparently was full of students and staff. The occasion was in December 1956. It is a classic lecture, strictly built on the theology of Abraham Kuyper. He argues for diversity on basis of one human race. Towards the end he comes out in clear language and it is unmistakable even though he phrases it in the negative. "[I]f we apply those principal truths to our circumstances in this multiracial country, then it is quite obvious that nobody on the basis of Scripture can also be a proponent of integration. Advocating a mixing of Whites, Coloureds and Bantus would clash straight away with the revealed will of God." 39

\section{Potgieter And Fundamentalism}

\section{Preliminary Findings}

In the contrast reading we have undertaken Potgieter appears from the start to come close to what I have defined as contemporary fundamentalism. A select tradition is certainly there, partly in the consistent emphasis on the plurality of (scriptural) truths and principia as the (only) real foundation. Predictably this select tradition is also ultimately used in the present socio-political situation. It is used to legitimise the order of apartheid. It is a realized

\footnotetext{
${ }^{39}$ Engdahl, p. 136, Potgieter, Veelvormige Ontwikkeling, die Wil van God, (Rede gelewer by geleentheid van die sluiting van die Teologiese Kweekskool te Stellenbosch, Desember 1956). Bloemfoentein, 1957:7. See also Potgieter, 'Is die Apartheidsbeleid Moreel te Regverdig?' in HB Thom (ed.), Grense, 'n simposium oor rasseen ander verhoudinge. Stellenbosch, 1961:22-36, Potgieter's reference to RF Alfred Hoernlé, South African Native Policy and the Liberal Spirit. Cape Town, 1939 (Engdahl, pp. 128f) and Potgieter, 'Die Apartheidsvraagstuk', editorial in Die Gereformeerde Vaandel XVIII, no. 1:2-4.
} 
eschatology in the sense that this theology plays an active role in working towards "a total reconstitution of the social and political order". ${ }^{40}$

The fundamentalist milieu is also there, a kind of enclave mentality, which is discernible even when after 1948 the minority Afrikaner people became the ruling elite. There was a strange interplay between being modern and anti-modern. "To plug into the whole comprehensive programme of apartheid policy, with its radical social engineering (Bantu Education, etc.) is nothing but embracing modernity."41 "What is emerging is nothing but a fundamentalist theology, not in the first place biblical fundamentalism but contemporary fundamentalism." ${ }^{42}$

Potgieter's theology is a cul-de-sac theology. It is extremely confined to his times. Just as it is difficult to stick to neo-Calvinism as it was understood in the first part of the $20^{\text {th }}$ century, it is well-nigh impossible to make use of a theology that plugged into the system of apartheid as did Potgieter's.

\section{Potgieter Embodying Afrikaner Fundamentalism}

As has been demonstrated it is quite possible to get a clear cut view of contemporary fundamentalism. No doubt the Fundamentalism Project has helped us a lot in that regard. ${ }^{43}$ It is, however, difficult to understand that no mention is made in this huge five-volume project of South African Afrikaner fundamentalism. The whole milieu is there for a long time for all to see. Clear signs can be seen from the middle of the $19^{\text {th }}$ century. Liberal ideas, especially those dressed up in a theological costume were suspect. Influences of such a kind, be it from the Netherlands or England, were to be stopped. The British dominance during the first part of the $20^{\text {th }}$ century through English speaking white South Africa also included an element of a more secular culture that alarmed Afrikaner people. All the while indigenous Africans made their presence felt in an ever increasing fashion. It is therefore not an exaggeration to state that an enclave mentality was long in the making. The same goes for the idea of a select tradition. Here of course the word varied, and there were in fact a number of theological streams within Afrikanerdom itself. However, what emerged as a dominant interpretation was a select tradition that had a Calvinist allegiance to Holy Scripture, regarded church as a secondary body in relation to people identity, saw a clear link between God's chosen people Israel and a select people of God on the southernmost tip of Africa and also that there was a holy calling as a people to fulfil the mission task of God to the other peoples. In the last instance there was soon developed a special conviction of a particular mission policy of separate developments for different race based churches, a policy that also came to serve as an inspiration for the apartheid ideologues.

All in all, the scene is set for contemporary fundamentalism on South African ground. What was missing for the first few years was the political implementation of the irreducible religious convictions. The latter were there for quite a time, apartheid politics in its pure form only from 1948 onwards. As I have tried to demonstrate in my dissertation, Potgieter could be seen as one of the ultraconservative theologians at Stellenbosch, but the truth is that he was by far more influential than that. In serving apartheid political ends his theology becomes not conservative but rather contemporary fundamentalist.

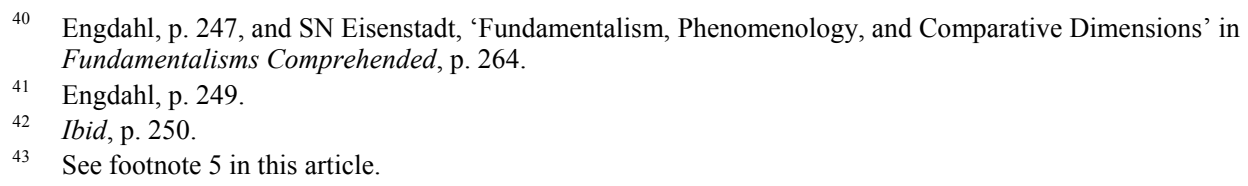


One should not deny that there are other interpretations of his theology and I have also demonstrated that in my thesis when dealing with Potgieter from a deconstructive point of view. Nevertheless, I think we have here a very clear case of contemporary fundamentalism. Through linking up with apartheid political convictions Potgieter's theology becomes fully predictable. There is nothing much more to say. Eschatology becomes realized eschatology in the form of a ready-made dispensation for the various population groups. In his case it was perfectly conducive to his own research from Calvin onwards on the fact of plurality in revelation and in creation (common grace). It becomes a closed system that does not allow surprises. The unholy alliance between religion and politics also opens the way for what is in reality totally alien to theology: insensitivity towards coercion and violence. After all, time is limited or even up, eschatology has to be fulfilled now not then, and there is no room for those still hesitating. It is here easy enough to be reminded of some of the contemporary fundamentalist movements keeping us awake in the $21^{\text {st }}$ century. 